\title{
Nefrolitiaziste Tıbbi Beslenme Tedavisi
}

\author{
Medical Nutrition Therapy in Nephrolithiasis
}

\section{Esra Köseler Beyaz ${ }^{1}$}

Geliş tarihi/Received: 05.03.2018 • Kabul tarihi/Accepted: 12.11.2018

\section{ÖZET}

Dünya çapında nefrolitiazisin prevalansı ve insidansının giderek arttığı bildirilmektedir. Son yıllarda nefrolitiazis alanında önemli ilerlemeler kaydedilmiştir. Taş oluşum nedenleri ve spesifik moleküler defektler daha kapsamlı olarak ortaya konulmaktadır. İdrar yoğunluğunun yanında idrarda çözünen kristallerin miktarı da böbrek taşı oluşumunda etkilidir. İdrar hacminin azalmasıyla birlikte idrardaki çözünen maddelerin saturasyanu değişir ve taş oluşum riski artar. İdrarda okzalat ve fosfor gibi bazı maddelerin yüksek düzeyi ile böbrek taşları oluşabilmektedir. Genler, metabolik ve çevresel etmenler idrar bileşimini etkileyebilmekte ve taş oluşum riskini arttırabilmektedir. Diyet de böbrek taş oluşumuna neden olabilen ya da taş oluşumunu önleyebilen bir etmendir. Diyet uygulamasındaki değişiklikler ise böbrek taşlarının tedavisinde ve önlenmesinde anahtar bir rol oynayabilmektedir. Böbrek taşlarının ortaya çıkışının ya da yenilenmesinin önlenmesinde idrar süper saturasyonunun azaltılması önemlidir. Bu yüzden idrar hacmi 2-2.5 litre olana kadar sıvı alımının arttırılması hedeflenmelidir. Diyetteki okzalat miktarı arttığında veya kalsiyum düşük olduğunda ortaya çıkabilen hiperoksalüri, kalsiyum okzalat taşı oluşumu için risk etmenidir. Gereksiz diyetsel kalsiyum kısıtlamalarından kaçınmak ve okzalattan zengin besinleri diyette kontrol altına almak böbrek taşının önlenmesi için önemlidir. Artmış diyet sodyum alımı, kalsiyum renal tübüler geri emilimini azaltarak böbrek taşı için risk etmeni olan hiperkalsiüriyi tetikleyebileceği için, diyetle sodyum alımının düzenlemesine gidilebilmektedir. Bu yüzden böbrek taşı oluşumunu ve tekrarlamasını önleyebilmek adına çevresel etmenlerden özellikle beslenmenin de kontrol altına alınması gerekebilmektedir.

Anahtar kelimeler: Böbrek taşı, diyet, kalsiyum, okzalat

\section{ABSTRACT}

The prevalence and incidence of nephrolithiasis is reported to be increasing across the world. In recent years, significant progress have been made in the field of nephrolithiasis. The factors and the specific molecular defects leading to stone formation have been revealed extensively. Besides urine concentration, the amount of crystals dissolved in the urine is also effective in the formation of kidney stones. By decreasing urine volume, the solubility of the dissolved substances in the urine changes and the risk of stone formation increases. Kidney stones can be formed when substances in the urine, such as oxalate and phosphorus, become highly concentrated. The genetics, metabolic and environmental factors may affect the urine composition and increase the kidney stone formation. Diet is one of the factors that can promote or inhibit kidney stone formation. Dietary changes can play a key role in the treatment and prevention of kidney stones. Reducing the urinary supersaturation is important for the prevention or the reoccurence of kidney stone formation. Fluid intake should be increased up to 2 to $2.5 \mathrm{~L}$ per day. Hypoxaluria, which may occur as a result of high dietary oxalate or low calcium intake, is a risk factor for calcium oxalate stone formation. It is important to avoid unnecessary dietary calcium restrictions,

1. İletişim/Correspondence: Başkent Üniversitesi, Sağlık Bilimleri Fakültesi, Beslenme ve Diyetetik Bölümü, Ankara, Türkiye • E-posta: koseler@baskent.edu.tr (1) https://orcid.org/0000-0001-7713-7871 
and oxalate-rich foods should be restricted to prevent kidney stones. Dietary sodium intake should also be considered, since increased sodium intake may trigger hypercalciuria, a well-known risk factor for kidney stones, by reducing the renal tubular reabsorption of calcium. Thus, the environmental factors, particularly diet, should be managed for the prevention and reoccurence of kidney stones.

Keywords: Kidney stone, diet, calcium, oxalate

\section{GİRIŞ}

Üriner sistem taş hastalığı, idrar yollarında taşın mevcut olması ile tanımlanır. Dünyada prevalansı yüksek olan, endüstrileşmiş toplumlarda giderek artmakta olan ciddi bir sağlık sorunudur. Üriner sistemde taş oluşumu çevresel, anatomik ve genetik etmenlerin karşllıklı etkileşimine dayanan çok etmenli bir olaydır (1).

Konsantre idrar içerisinde atılan tuzlar ve mineraller böbreklerin iç yüzeyinde tübül denilen ünitelerde zamanla taşa dönüşecek kristaller halinde çökeltiler oluşturarak taş haline gelir. Böbrek taşları, kalsiyum okzalat, kalsiyum fosfat, ürik asit, sistin ve sürtivit taşlarından oluşmaktadır. Tipik olarak, kalsiyum oksalat veya kalsiyum fosfat en sık karşılaşılan türler olup, tüm taş oluşumlarının \%70-75'ini oluşturmaktadır (2).

Amerika ve Avrupa'da böbrek taşı görülme sıklığının \%0.1-0.4, Asya toplumunda \%2-5, Avrupa ve Kuzey Amerika'da \%8-15 ve Suudi Arabistan'da \%20 olduğu tahmin edilmektedir. Böbrek taşları tekrarlama eğilimi göstermektedir ve yenileme oranı 20 yll süresince $\% 75$ civarındadır (3).

\section{Böbrek Taşı Oluşumunun Belirtileri}

Böbrek taşlarının çoğunluğu bulgu vermemekle birlikte radyolojik incelemeler sirasinda saptanmaktadır. Bulgu veren böbrek taşlarına ise sıklıkla ağrı, enfeksiyon, kolik, bulantı, kusma, karın şişliği, idrarda kanama eşlik etmektedir. Böbrek taşı olan bireylerde kullanılan tanı testleri arasında ise primer hiperparatiroidizm, kronik böbrek hastalığı, renal tübülerasidoz, hiperkalsiüri, ürik asit süpersatürasyonunun hesaplanması ve kalsiyum fosfat ve ürik asit süper saturasyonunun hesaplanması adına kan testleri, 24 saatlik idrar toplama, üriner sistin incelemesi ve taş analizi vardır (1).

Böbrekte oluşan fizyolojik ve anatomik bozukluklar, hipertansiyon varlığı, bazı ilaçlar, bağırsak hastalıkları, endokrin bazı bozukluklar, obezite ve enfeksiyonlar taş oluşmasina neden olan etmenlerin idrarla atılımında artışa ve kristallerin çökelmesine neden olabilmektedir (4).

Düşük idrar hacmi, okzalat, ürik asit, asit pH, stasis, kalsiyum, konjenital böbrek bozuklukları, paratiroid hormon bozuklukları, ilaçla tedavisi, gut, hipertansiyon, kolitis, kolon inflamasyonu, kronik diyare, irritable bağırsak hastalıkları, renal tübüler asidoz, Crohn's hastallğı sonucu dehidratasyon ve düşük sitrat, artirit, üriner enfeksiyonlar, böbrek taşı için görülmüş tıbbi tedavi, obezite, uzun süren hareketsizlik, anatomik nedenler böbrek taş oluşum riskini arttırırken, yüksek idrar hacmi ve akımı, sitrat, glikoproteinler ve magnezyum böbrek taş oluşum riskini azaltmaktadır (4).

\section{Böbrek Taşları ve Beslenme}

Böbrek taşlarını tekrarlama olasilığ oldukça yüksektir (\%80). İlk taştan sonra rekürens riski ilk beş yllda $\% 40$, yirmi yılda ise $\% 75$ olarak belirlenmiş olup, taş ne kadar erken yaşta oluşuyorsa taşın tekrarlama olasılı̆̆ı da o kadar yüksek olarak saptanmıştır. Bu yüzden böbrek taşı oluşumunu ve tekrarlamasını önleyebilmek adına çevresel bazı etmenlerin kontrol altına alınabilmesi gerekebilmektedir. Yaş ve cinsiyet, sıvı alımı, genetik, coğrafya, iklim ve mevsimsel etkenler, meslek gibi diğer birçok etmen 
de taş hastalığında önem arz etmektedir. Beslenme alışkanlıkları da taş oluşumunda rol oynayabilen önemli çevresel etmenler olarak belirlenmiştir (1).

\section{Sivı Alımı}

Böbrek taşının önlenmesinde en etkili diyet önerilerinden biri hastaların sıvı alımının arttırılmasıdır. Artan sivı alımı, idrar hacmini arttırması, dilüe idrar oluşumunu ve diürezi arttırması nedeniyle, kristallerin üreteri daha hızlı terk etmesini sağlayarak taş oluşumunu engellemektedir. Yeterli sıvı alımı, tek başına üriner sistem taş oluşum ve tekrarlama risklerini azaltabilmektedir (5).

Amerika Ulusal Diyabet, Sindirim ve Böbrek Hastalıkları Enstitüsü gün içerisinde 2-3 L sıvı alımının sağlanması gerektiğini belirtmektedir. İklim koşullarına ve bireyin fiziksel aktivite düzeyine göre bireysel gereksinmenin değişebileceği bildirilmektedir. Sistin taşlarının varlığında, bireyin daha fazla sıvıya gereksinme duyulabileceği de bildirilmektedir. En iyi sıvı tercihinin ise su olduğu ifade edilmektedir. Limonata, portakal suyu gibi içeceklerin de sitrat içeriğinden dolayı taş içindeki kristal büyümesini önlediği ifade edilmektedir (6).

Amerikan Üroloji Birliği böbrek taşları için belirtmiş olduğu tıbbi beslenme tedavisinde, bütün taş türlerinde, günde $2 \mathrm{~L}$ ve üzerinde idrar hacmine ulaşabilmek için günlük su tüketiminin en az $2.5 \mathrm{~L}$ olması gerektiğini vurgulamaktadır (Standart, Kanıt B düzeyi) (7).

Avrupa Üroloji Birliği de günde en az 2.5 L idrar hacmine ulaşana kadar sıvı alımının arttırılması gerektiğini belirtmektedir (Derece: A). Amerikan Hekimleri Koleji'ne göre ise günde en az 2.0 L idrar hacmine ulaşana kadar sıvı alımı arttırılmalıdır (8).

Kanada Üroloji Birliği kalsiyum taşı olan bireylerde, idrar çıkışı en az 2.0 L/gün olana kadar sıvı alımının arttırılması gerektiğini (Kanıt A-C düzeyi, Derece 1-3), ürik asit taşı olan bireylerde sıvı alımının arttırılması gerektiği (Kanıt C düzeyi, Derece 3-4), sistin taşı olan bireylerde idrar çıkışı >3 L/gün olacak şekilde sıvı alımının arttırılması gerektiği belirtilmektedir (Kanıt C düzeyi, Derece 3-4) (1).

Günlük idrar hacmi 2 L'den daha fazla olan bireylerde böbrek taşı yenileme riskinin azaldığı belirlenmiştir (9). Çünkü idrar hacminin artması kalsiyum oksalat, kalsiyum fosfat ve mono sodyum ürat açısından doygunluğun azalmasına yol açarak taş oluşum riskini azaltmaktadır (10). Literatürde de bu sonuca uyumlu olarak idrar hacminin azalması sonucu idiyopatik kalsiyum taşı sıklığının arttığı belirtilmektedir (5). Sistin taşlarının tekrarının önlenmesi için günde 3 L'den fazla sıvı alımının idrar sistin atımı kalıntılarını önleyebileceği ifade edilmektedir (11).

Kadınlarda, 17 farklı yedi içecek türü ile böbrek taşı arasındaki ilişkiyi incelemek için planlanmış bir araştırmada, 40-65 yaşları arasında 553.081 kadın 8 yll süresince izlenmiştir (12). Kadın bireylerin 719'unda böbrek taşı saptanmıştır. Çalışma sonunda toplam sıvı alımı en düşük olan gruba göre, en yüksek olan grupta böbrek taşı riski 0.62 kat daha fazla bulunmuştur. Toplam sıvı alımının böbrek taşı riskini azaltırken, içecek seçiminin ön plana çıktığına dikkat çekilmiştir (12). Gazlı içeceklerin taş riskini arttırdığı ifade edilmektedir. Gazlı içecekler, litojenik fosforik asit ve sitrik asit içermeleri nedeniyle, idrar kompozisyonu üzerinde etkiye sahiptir $(13,14)$.

Epidemiyolojik çalışmalarda, yüksek fruktozlu mısır şurubu kullanımındaki artışla paralel olarak, böbrek taşı görülme sıklığında da bir artış olduğu bildirilmiştir. Yüksek fruktozlu beslenme, hipomagnezemi, hiperürisemi, ürik asit atılımının artması, yüksek okzalat atılımı (özellikle düşük $\mathrm{B}_{6}$ vitamini alımılla birlikte) ve hiperkalsiüri taş oluşum riskini arttırmaktadır. Fruktoz ve taş oluşum riski arasındaki mekanizmalar tam olarak bilinmemekle birlikte fruktoz alımının idrar oluşumu üzerine etkisiyle ilişkili olabileceği bildirilmiştir. Fruktoz, üriner kalsiyum, okzalat ve ürik asit atımını arttırmaktadır. Bu durum taş oluşum riskini arttırmaktadır. Fruktoz alımı insülin duyarlılığını azaltmaktadır. İnsülin direnci de ürik asit ilişkili böbrek taşı oluşumu için bir risk etmenidir. Fruktoz, 
ürik asit düzeylerini de arttırmaktadır. Böylelikle de bu durum ürik asit kristallerinin çökelmesine ve taş oluşumuna neden olmaktadır (15-17).

Fruktoz alımının böbrek taşı oluşum riskine etkisini inceleyen 48 ylllık bir prospektif çalışmada yeni tanı alan 4.902 böbrek taşı hastasının günlük diyetleri ile birlikte yüksek fruktoz alımının olduğu belirlenmiştir (18).

\section{Sodyum}

Düşük sodyumlu diyet, okzalat ve kalsiyum atımını önemli ölçüde azaltmaktadır (19). Sodyum ve kalsiyum renal tübülde aynı bölümden emildiği için sodyum, idrar ile kalsiyum atımını arttırmaktadır. Artmış diyet sodyum alımı, kalsiyumun renal tübüler geri emilimini azaltarak hiperkalsiüriyi tetiklemektedir. İdrardaki yüksek kalsiyum ise okzalat ve fosfor ile birleşip taş oluşturabilmektedir. İdrarda sistini azaltmak için de sodyum alımının azaltılması yararlı olabilmektedir (20). Amerika Ulusal Diyabet, Sindirim ve Böbrek Hastalıkları Enstitüsü’ne göre böbrek taşı riski, günlük sodyum alımı ile artmaktadır. Bu yüzden kalsiyum okzalat veya kalsiyum fosfat taşı olan bireylerde sodyum alımının önerilen günlük alım miktarının (RDA) düzeylerinin altına (2300 mg) sınırlandırılması gerektiği vurgulanmaktadır (6). Avrupa Üroloji Birliği (8) ve Kanada Üroloji Birliği (Kanıt A-C düzeyi, Derece 1-3) (1) kalsiyum taşı olan bireylerde günlük sodyum alımının $<2300 \mathrm{mg}$ olması gerektiğini belirtmektedir. Amerikan Üroloji Birliği, sistin taşı olan bireylerde sodyum alımının "uzman görüşü” ile sınırlandırılması gerektiğini, kalsiyum taşı olan bireylerde ise sodyum sinırlaması gerektiğini ifade etmiştir (Kanıt B düzeyi, Standart) (8).

\section{Protein}

Aşırı hayvansal protein alımı, hiperkalsiüri, hiperürikozüri, hiperokzalüri, düşük idrar pH’sı ve hipositratüri gibi çeşitli üriner risk etmenlerini etkileyerek böbrek taşı riskini arttırabilmektedir (2).

Yüksek hayvansal protein alımı sülfür üretimini arttırmaktadır. Oluşan bu asit yükünü nötralize etmek için kemik, fosfat ve karbonat sağlamaktadır. Dolayısıyla kemikteki bu çözünmenin diğer bir ögesi olan kalsiyumun, idrarla atımı artmaktadır. Asit yükü, distal tübülden kalsiyum emilimini doğrudan azaltmaktadır. Asit-baz durumundan bağımsız olarak, sülfür metabolizmasıyla artan idrar sülfat atımı, idrar kalsiyum atımını doğrudan arttırmaktadır (2). Ürik asit taşına sahip bireylerin ise yaklaşık \%70’inin pürinden zengin bir diyet (organ etleri, biftek, ördek, balık) tükettikleri belirlenmiştir. Bu hastalarda diyet pürin kısıtlanması ile ürik asit atımının normale döndüğü görülmüştür. Ürik asit taşına sahip bireylerde, organ etleri, biftek, ördek, balık, sakatat, ançüez, ringa balığı, sardalya ve et suyu gibi pürinden zengin besinlerin tüketiminin $225 \mathrm{~g} /$ gün olarak sinırlanması önerilmiştir. Metioninden zengin besinlerin (süt, et ve yumurta) kisitlanmasinın ise, toplam idrar sistin atımında klinik olarak bir değeri olmayan çok küçük azalmaya neden olduğu belirtilmektedir (21).

Amerika Ulusal Diyabet, Sindirim ve Böbrek Hastalıkları Enstitüsü'ne göre yüksek miktarda tüketilen hayvansal proteinin, kalsiyum atımını arttırarak, sitrat atımını azaltarak kalsiyum taşı oluşumu için risk oluşturduğu belirtilmiştir. Bu yüzden ürik asit taşı olan bireylerde et tüketimlerinin $180 \mathrm{~g} /$ gün olacak şekilde sınırlandırılması önerilmektedir (6).

Amerikan Üroloji Birliği, kalsiyum taşı olan hastaların meyve-sebze tüketimlerini arttırmaya, süt ürünleri kaynaklı olmayan hayvansal protein alımlarını sınırlandırmaya yöneltilmesi gerektiğini, kalsiyum taşı ve ürik asit taşı olan hastaların süt ürünleri kaynaklı olmayan hayvansal protein alımlarını sınırlandırmaya yöneltilmesi gerektiği ve sistin taşı olan hastaların protein alımlarını sinırlandırmaya yöneltilmesi gerektiği “uzman görüşü” olarak belirtmektedirler. Avrupa Üroloji Birliği hayvansal protein alımının sinırlandırılması gerektiğini belirtirken (8), Kanada Üroloji Birliği kalsiyum taşı olan bireylerde (Kanıt A-C düzeyi, Derece 1-3) ve ürik asit taşı (Kanıt A-C düzeyi, Derece C) olan bireylerde, hayvansal protein alımının azaltılması (günde 2 öğünden az, <180-240 g/gün) gerektiğini belirtmektedir (1). 
Kalsiyum taşı olan bireylerde, diyet proteini alım önerisi vücut ağırlığı (kg) başına günlük 0.8-1.0 g şeklinde ifade edilmektedir (20). Hiperkalsiürili erkeklerde yapılan randomize kontrollü bir araştırmada, düşük hayvansal protein, sodyum, okzalat ve normal düzeyde kalsiyum alan bireylerde 5 yıllık süreçte yeniden taş oluşum riskinin \%50 azaldığı belirlenmiştir (22). Amerika'da yapılan bir araştırmada ise, düşük proteinli diyet alımının 4.5 ylllık süreçte yeniden taş oluşum riskini azaltmadığı belirlenmiştir (23). Beş ylllık randomize kontrollü bir araştırmada, iki farklı diyetin taş oluşum riski değerlendirilmiştir. Önerilen miktarda kalsiyum (1200 mg/gün), azaltılmış sodyum ve hayvansal protein (sırasıyla $50 \mathrm{mEq} / g u ̈ n$ ve $52 \mathrm{~g} /$ gün) tüketen bireyler ile düşük kalsiyum (400 mg/gün) tüketen bireyler 5 yll süresince incelenmiştir. Önerilen miktarda kalsiyum (1200 mg/gün), azaltılmış sodyum ve hayvansal protein (sirasıyla $50 \mathrm{mEq} /$ gün ve $52 \mathrm{~g} /$ gün) tüketen bireylerde beş yllın sonunda taş riskinin 1.5 kat azaldığı belirlenmiştir (22).

\section{Omega-3 Yağ Asitleri}

Omega 3 yağ asidi, böbrek taşı olan bireylerde, idrar kalsiyum ve okzalat atımını azaltarak, hücresel fosfolipit araşidonik asit içeriğini azaltmakta, eritrosit ve renal iyon transportunu normalize etmektedir. Ancak balık proteininin yüksek oranda pürin içerdiği ve bu durumun da ürik asit düzeyini arttırdığı, hiperürikozüri ve hiperkalsiüri sonucunu doğurduğu unutulmamalıdır (24).

\section{Kalsiyum ve Okzalat}

Önceleri kalsiyum okzalat taşlarının tıbbi beslenme tedavisinde, kalsiyumdan zengin besinlerin sınırlandırılması ve kalsiyum okzalat taşlı bireylerin düşük kalsiyum içeriği olan bir diyet tüketmelerinin gerekliliği ifade edilirken, son ylllarda düşük kalsiyumlu diyetlerin kalsiyum okzalat taşlarının önlenmesinde ve tedavisinde etkin olmadığı görülmektedir (25). Hiperkalsiüri, kalsiyum iyon aktivitesini ve kalsiyum tuzlarının saturasyonunu arttırarak kalsiyum tuzlarının kristalize olmasını uyarabilmektedir. Ayrıca yüksek idrar kalsiyum düzeyi, kalsiyum tuzu oluşumuna ve çökelmesine karşı üriner inhibitör aktivitesini zayıflatarak kalsiyum okzalat veya kalsiyum fosfat taş oluşumuna neden olabilmektedir. Ancak besinlerle tüketilen kalsiyumun, kalsiyum okzalat taşı riskini arttırmadığı bildirilmektedir (6). Üriner kalsiyumun atımını kalsiyum, magnezyum, sodyum, alüminyum gibi mineraller, karbonhidratlar ve idrarın asit yükü (hayvansal protein) arttırmaktadır. Üriner kalsiyumu azaltan maddeler ise potasyum, fosfor ve idrarm alkali yüküdür (meyve ve sebzeler).

Hiperokzalüri (>40 mg okzalat/günlük idrar) kalsiyum taşının oluşmasında önemli role sahiptir. Üriner okzalatın büyük bir bölümü (\%55-70) gliokzalat ve askorbik asit metabolizması sonucu oluşmaktadır. Normalde sağlıklı bir birey günde 15-40 mg okzalatı idrarla atmaktadır ve bu oran okzalattan zengin beslenme uygulandığında \%50 oranında artmaktadır. Diyet okzalatı üriner okzalatı etkilemektedir. Çünkü okzalatın atım yolu sadece renal yolla olmaktadır. Normal bir diyetin okzalat içeriği 44-350 mg/gün'dür. Batı diyetlerde ise günlük ortalama okzalat alımının 100-150 mg olduğu bildirilmektedir. Normal bireylerde sindirilen okzalatın sadece \%6-14'ü emilirken, böbrek taşı olan bireylerde, normal bireylere göre emilimin $\% 50$ oranında daha fazla olduğu belirlenmiştir $(2,26)$. Besinlerle tüketilen kalsiyum ise, kalsiyum okzalat taşı riskini arttırmamakla birlikte aynı zamanda bağırsaklarda okzalata bağlanarak okzalat emilimini ve idrar düzeyinin azalmasını sağlamaktadır. Diyette kalsiyumun sinırlandırılması hiperoksalüri için potansiyel bir risk teşkil edebilmektedir. Aynı zamanda kemik mineral kaybı ve taş oluşumu için de risk etmeni oluşturabilmektedir (2). Genel önerilere bakıldığında kalsiyum taşı olan bireylerde, diyetle kalsiyum alımının 800-1000 mg/gün olması, yaş ve cinsiyete özgü alım önerilerinin altına inilmemesi belirtilmektedir (20).

Amerikan Üroloji Birliği böbrek taşları için belirtmiş olduğu tıbbi beslenme tedavisinde, idrar okzalat atımı yüksek olan ve kalsiyum okzalat taşı olan bireylerin okzalattan zengin yiyecek alımının sinırlandırılması 
ve kalsiyum alımının (1000-1200 mg) normal düzeyde tutulması gerektiğini belirtmektedir (Standart, Kanıt B düzeyi) (7).

Avrupa Üroloji Birliği de kalsiyum taşı olan bireylerin 1000-1200 mg/gün kalsiyum tüketmeleri gerektiğini belirtmektedir (Kanıt A düzeyi) (8). Kanada Üroloji Birliği de kalsiyum taşı olan bireylerde, öneriler ölçüsünde kalsiyum alımı sağlanmasını (1000-1200 mg/gün), okzalattan zengin besinlerin (1spanak, çilek, yağlı tohum, yaban muzu, buğday tohumu, bitter çikolata, kakao, demleme çay) ve C vitamini alımının $\quad(<1000 \quad \mathrm{mg} /$ gün$) \quad$ sinırlandırılmasını (Kanıt A-C düzeyi, Derece 1-3), hiperoksaloürili kalsiyum taşı olan bireylerin de düşük okzalatlı diyet ile tedavi edilmesini (Kanıt C düzeyi, Derece 2-3) önermektedir (1).

Kalsiyum alım durumu ve kalsiyum okzalat taşı riskini irdeleyen bir araştırmada, 12 yll boyunca izlenen 91,731 kadından 864'ünde böbrek taşı belirlenmiştir (27). Bireylerin diyetle kalsiyum alımı ve böbrek taşı riskinin negatif ilişkisi olduğu saptanmıştır (en düşük diyet kalsiyum alan gruba göre, en yüksek alan grupta hastalık oluşum riski 0.65 'dir). Kalsiyum desteği ile böbrek taşı riskinin ise olumlu ilişkili olduğu belirlenmiştir (En düşük kalsiyum desteği alan gruba göre, en yüksek alan grupta hastalık oluşum riski 1.20'dir). Çalışma sonucunda, yüksek diyet kalsiyum alımının semptomatik böbrek taşı riskini azaltabileceği, destek olarak alınan kalsiyumun ise riski arttırabileceği sonucuna varılmıştır. Diyetle alınan kalsiyumun, okzalat emilimini azalttığı da belirtilmiştir (27). Hastaların diyet planlamasında yüksek okzalatlı besinlerden (ıspanak, buğday kepeği, yer fıstığı, ravent (yayla muzu), pancar, çikolata, tahin, beriler, kakao, çay, buğday tohumu, pekan cevizi, çikolata) uzak durmaları ve okzalat emilimini azaltmak için yüksek kalsiyum içeriği olan besinlerin tüketimi önerilir (150 mg kalsiyum 100 mg okzalatı bağlar) $(2,6,20)$. Hiperkalsiürili hastalarda kalsiyum kısıtlamasından, kemik mineral yoğunluğunu azaltması ve kırık riskini arttırması nedeniyle sakınılmalıdır $(28,29)$.

\section{Probiyotikler}

Bağırsaktaki probiyotiklerin bir bölümünü, bağırsaktaki okzalatı tüketen, dolayısıyla okzalat emilimini sinırlayan aerobik bakteriler (Oxalobacterformigenes) oluşturmaktadır. Bağırsak florası bozuk olanlarda bu bakterilerin sayısı azalmaktadır. Bu nedenle de ortamdaki okzalat miktarı artmaktadır. Bu yüzden sağlıklı bir bağırsak florası kalsiyum okzalat taşlarının önlenmesine katkı sağlamaktadır (30).

\section{Vitamini}

Askorbik asit, metabolize olduğu zaman okzalata dönüşmektedir. Fazla C vitamininin, böbrek taşı oluşumunda rol oynayabileceği öne sürülmektedir. Yapılan bir araştırmada, 40-75 yaşları arasında değişen taş hikayesi olmayan 45,251 erkek 6 yll izlenmiş, C vitamini alımı ile taş arasında bir ilişki araştırılmış, ancak daha fazla C vitamini kullananlarda daha fazla böbrek taşı olduğuna dair güçlü bir delil saptanmamıştır (31). Diğer bir araştırmada günde $<250 \mathrm{mg}$ ve <1500 mg C vitamini tüketenler arasında taş riski açısından bir farkın olmadığı belirlenmiştir (32). Yapılan bir meta analiz çalışmasında da fazla C vitamini kullananlarda daha fazla böbrek taşı olduğuna dair güçlü bir ilişki saptanamamıştır (33). Bugüne kadar C vitamini için üst limiti önerisinin 2000 mg/gün olduğu gösterilmiştir. Askorbik asitin 500 mg ve üzerinde alımının sağlık yararları net ortaya konulamadiğından, özellikle kalsiyum okzalat taş riski olan bireylerde, önerilerin üzerinde tüketilen C vitamini, hiperoksalozise neden olacağından kalsiyum okzalat taşı oluşumuna neden olabilmektedir. $\mathrm{Bu}$ yüzden alımın 500 mg/gün’ün üzerine çıkılmaması önerilmektedir (34). Hiperokzalaüri durumunda hem diyet okzalat hem de askorbik asit alımının $100 \mathrm{mg}$ / gün’ün altında alınması da belirtilmektedir (20). 


\section{Hipositratüri}

İdrar sitrat düzeyi, kalsiyum taş oluşumuna karşı idrar kalsiyum çökelimi için önemli bir belirleyicidir. İdrar kalsiyumu, kalsiyum ile birleşmiş çözünür tuz formlarını bağlamaktadır. Böylelikle kalsiyum fosfat ve kalsiyum okzalata karşı üriner saturasyonu azaltmaktadır. Okzalat ve fosfat birikimini önlemektedir. Açlık durumunun tetiklenmesi ve diyet potasyum alımının azalması da idrar sitrat düzeylerini azaltabilmektedir (2). Kanada Üroloji Birliği kalsiyum taşı olan bireylerde, sitrattan zengin içecek (limonata, portakal suyu) tüketiminin arttırılması gerektiğini belirtmektedir (Kanıt A-C düzeyi, Derece 1-3) (1).

\section{Magnezyum}

Magnezyum, okzalatla suda çözünür kompleks oluşturmaktadır. Bu şekilde okzalatın emilimini baskılamakta ve üriner okzalat atımını azaltabilmektedir (35). Yapılan bir izlem çalışmasında, diyet magnezyum alımı ile böbrek taşı riski arasında ters bir ilişki belirlenmiştir (36).

\section{B $_{6}$ Vitamini}

$\mathrm{B}_{6}$ vitamini yetersizliği okzalat üretimi ve okzalüriyi arttırmaktadır. Kalsiyum okzalat taşı oluşan bireylerde 2-10 mg/gün $\mathrm{B}_{6}$ vitamin alımının üriner okzalatı azalttığı belirlenmiştir (37).

\section{Potasyum}

Potasyum alımı üriner sitratüri ile ters ilişkilidir. Taş oluşum insidansını \%50 oranında azaltan potasyum alım düzeyi 4680 mg/gün olarak belirlenmiştir. Yapılan bir araştırmada, kalsiyum alımları en yüksek olan grubun sıvı, potasyum (alkali) ve magnezyum alımlarının da daha yüksek olduğu saptanmıştır (37).

\section{Posa}

Hemşire Sağlık Çalışması'nda kadınlarda diyet fitat miktarı, böbrek taş oluşumu ile ters ilişkili bulunmuştur. Diyet posası, kalsiyum okzalat ve kalsiyum fosfatın kristalizasyonunda inhibitör etki göstermektedir. Aynı zamanda hiperkalsiüriyi azaltmak için kalsiyumla kompleks oluşturmaktadır (38).

\section{Obezite}

Obezite, insülin direnci ve hiperinsülinemi ile ilişkilidir ve üriner kalsiyum atımını arttırarak kalsiyum taş oluşumunu arttırmaktadır. Ayrıca fazla kilolu olmanın, ürik asit taş oluşum riskini arttırdığı saptanmıştır (6). Obez bireylerde metabolik değişiklikler nedeni ile idrar taşı oluşum riskinin arttığı belirlenmiştir. Yapılan bir araştırmada, beden kütle indeksi (BKİ) $>30 \mathrm{~kg} / \mathrm{m}^{2}$ olmasıyla böbrek taşı oluşumu arasındaki ilişki anlamlı bulunmuştur. BKİ artışıyla hastalarda hafif metabolik asidoz gelişmektedir. $\mathrm{Bu}$ durumda idrar asit atımı artışı (pH üre azalır) ve sitrat atılımının azalışı gözlemlenmektedir (39).

\section{Böbrek Taşı ile İlişkili Diğer Etmenler}

Düşük karbonhidratlı diyetin, özellikle ürik asit taş oluşum riskini arttırdığı ifade edilmektedir. Hipertansiyonu Önlemek İçin Diyet Yaklaşımları'nda (DASH) yüksek meyve ve sebze, orta-az yağlı süt ürünleri ve düşük hayvansal protein içeriği nedeniyle böbrek taşı riskini azaltabileceği belirtilmektedir (6).

Yeme bozukluklarına sıklıkla eşlik eden kusma ve laksatif kullanma gibi arındırma alışkanlıkları, kalsiyum okzalat taşı ve kalsiyum fosfat taşı oluşum riskini arttırabilmektedir. Ayrıca protein tozlarının kullanım miktarı ve sıklığının arttığı durumlarda ve yüksek şeker içeren diyetlerin kronik kullanımı ile de yine kalsiyum okzalat taşı ve kalsiyum fosfat taşı oluşum riskinin arttığı belirtilmektedir $(20,40)$. 


\section{SONUÇ VE ÖNERILER}

Böbrek taşlarının artan prevalansı ve insidansı nedeniyle, böbrek taşlarının tıbbi beslenme tedavisini net olarak ortaya koymak oldukça önemlidir. Özellikle yineleyen böbrek taşları için nedenlerin belirlenmesi, tanısal ayrılma ve tıbbi önleyici tedbirlerin geliştirilmesi, böbrek taşlarının tıbbi beslenme tedavisinde ilerleme kaydettirecek aşamalardır. Taşların, hiperkalsiüri, hipositratüri, hiperokzalaüri, hiperürikozüri, aşırı idrar asidi, sistinüri ve düşük idrar hacmi gibi çeşitli metabolik ve çevresel beslenme etmenleri nedeniyle geliştiği bilinmektedir. $\mathrm{Bu}$ nedenle hiperkalsiüri, hipositratüri, hiperokzalaüri, hiperürikozüri, aşırı idrar asidi, sistinüri ve düşük idrar hacmine neden olacak beslenme alışkanlıklarını kontrol altına almak hem böbrek taşı oluşumunu hem de taş yineleme riskini azaltmak için önemlidir.

Çıkar çatışması - Conflict of interest: Yazarlar çıkar çatışması olmadığını beyan ederler. - The authors declare that they have no conflict of interest.

\section{KAYNAKLAR}

1. Paterson R, Fernandez A, Razvi H, Sutton R. Evaluation and medical management of the kidney stone patient. Can Urol Assoc J 2010;4(6):375-9.

2. Zerwekh JE. Nutrition and renal stone disease in space. Nutrition 2002;18(10):857-63.

3. Pak CYC. Kidney stones. Lancet 1998;351(9118):1797801.

4. Kızlltan G, Türker P. Böbrek hastalıkları ve beslenme tedavisi. Tüfekçi Alphan E, editör. Hastalıklarda Beslenme Tedavisi. 2. Baskı. Ankara: Hatipoğlu Yayınlarl; 2014. s.678-89.

5. Tefekli A, Tok A, Altunrende F, Barut M, Berberoğlu Y, Müslümanoğlu AY. Lifestyle and nutrition habits in urinary system stone patients. Turkish J Urology 2005;31(1):113-8.

6. Diet for Kidney Stone Prevention. National Kidney and Urologic Diseases Information Clearinghouse. National Institute of Diabetes and Digestive and Kidney Diseases. Avaliable at: https://www.niddk.nih.gov/healthinformation/urologic-diseases/kidney-stones/eatingdiet-nutrition Accessed December 23, 2018.
7. Pearle MS, Goldfarb DS, Assimos DG, Curhan G, DenuCiocca CJ, Matlaga BR, et al. Medical management of kidney stones: AUA guideline. J Urol 2014;192(2):316-24.

8. Ziemba JB, Matlaga BR. Guideline of guidelines: kidney stones. BJU Int 2015;116(2):184-9.

9. Borghi L, Meschi T, Amato F, Briganti A, Novarini A, Giannini A. Urinary volume, water and recurrences of idiopathic calcium nephrolithiasis: a 5-year randomized prospective study. J Urol 1996;155(3):839-43.

10. Bagnis CI, Deray G, Baumelou A, Le Quintrec M, Vanherweghem JL. Herbs and the kidney. Am J Kidney Dis 2004;44(1):1-11.

11. Grieff M, Bushinsky AD. Nutritional prevention and treatment of kidney stones. In: Kopple J, Massry S, Kalantar-Zadeh K, editors. Nutritional Management of Renal Disease. 3rd ed. Amsterdam: Elsevier; 2013. p.699709.

12. Curhan GC, Willett WC, Speizer FE, Stampfer MJ. Beverage use and risk for kidney stones in women. Ann Intern Med 1998;128(7):534-40.

13. Rodgers A. Effect of cola consumption on urinary biochemical and physicochemical risk factors associated with calcium oxalate urolithiasis. Urol Res 1999;27(1):77-81.

14. Ferraro PM, Taylor EN, Gambaro G, Curhan GC. Soda and other beverages and the risk of kidney stones. Clin J Am Soc Nephrol 2013;8(8):1389-95.

15. Nguyen NU, Dumoulin G, Henriet MT, Regnard J. Increase in urinary calcium and oxalate after fructose infusion. Horm Metab Res 1995;27(3):155-8.

16. Asselman M, Verkoelen CF. Fructose intake as a risk factor for kidney stone disease. Kidney Int 2008;73(2):139-40.

17. Knight J, Assimos DG, Easter L, Holmes RP. Metabolism of fructose to oxalate and glycolate. Horm Metab Res 2010;42(12):868-73.

18. Taylor EN, Curhan GC. Fructose consumption and the risk of kidney stones. Kidney Int 2008;73(2):207-12.

19. Nouvenne A, Meschi T, Prati B, Guerra A, Allegri F, Vezzoli G, et al. Effects of a low-salt diet on idiopathic hypercalciuria in calcium-oxalate stone formers: a 3-mo randomized controlled trial. Am J Clin Nutr 2010;91(3):565-70.

20. Worcester EM, Coe FL. Calcium kidney stones. N Engl J Med. 2010;363(10):954-63.

21. Alvarez Arroyo MV, Traba ML, Papado A. Hypocitraturia as a pathogenic risk factor in the mixed (calcium oxalate/ uric acid) renal stones. Urol Int 1992;48(3):342-6. 
22. Borghi L, Schianchi T, Meschi T, Guerra A, Allegri F, Maggiore U, et al. Comparison of two diets for the prevention of recurrent stones in idiopathi chypercalciuria. N Engl J Med 2002;346(2):77-84.

23. Hiatt RA, Ettinger B, Caan B, Quesenberry CP Jr, Duncan D, Citron JT. Randomized controlled trial of low animal protein, high fiber diet in the prevention of recurrent calcium oxalate kidney stones. Am J Epidemiol 1996;144(1):25-33.

24. Baggio B, Budakovic A, Angela M. Plasma phospholipid arachidonic acid content and calcium metabolism in idiopathic calcium nephrolithiasis. Kidney Int 2000;58(3):1278-84.

25. Williams CP, Child DF, Hudson PR, Davies GK, Davies MG, John R, et al. Whyoral calcium supplements may reduce renal stone disease: report of a clinical pilot study. J Clin Pathol 2001;54(1):54-62.

26. Holmes RP, Assimos DG. The impact of dietary oxalate on kidney stone formation. Urol Res 2004;32(5):311-6.

27. Curhan GC, Willett WC, Speizer FE, Spiegelman D, Stampfer MJ. Comparison of dietary calcium with supplemental calcium and other nutrients as factors affecting the risk for kidney stones in women. Ann Intern Med 1997;126(7):497-504.

28. Heilberg IP, Weisinger JR. Bone disease in idiopathic hypercalciuria. Curr Opin Nephrol Hypertens. 2006;15(4):394-402.

29. Lauderdale DS, Thisted RA, Wen M, Favus MJ. Bone mineral density and fracture among prevalent kidney stone cases in the third national health and nutrition examination survey. J Bone Miner Res 2001;16(10):18938.

30. Campieri C, Campieri M, Bertuzzi V, Swennen E, Matteuzzi D, Stefoni S, et al. Reduction of oxaluria after oral course of lactic acid bacteria at high concentration. Kidney Int 2001; 60(3):1097-1105.
31. Curhan GC, Willett WC, Rimm EB, Stampfer MJ. A prospective study of the intake of vitamins $C$ and $B_{6}$, and the risk of kidney stones in men. J Urol 1996;155(6):184751.

32. Gerster H. No contribution of ascorbic acid to renal calcium oxalate stones. Ann Nutr Metab 1997;41(5):26982.

33. Traxer O, Pearle MS, Gattegno B, Thibault P. Vitamin $C$ and stone risk. Review of the literature. Prog Uro 2003;13(6):1290-4.

34. Academy of Nutrition and Dietetics (A.N.D.), Evidence Analysis Library. Chronic kidney disease (CKD) guideline. Major Recommendations 2010. Avaliable at: https://www.andeal.org/vault/pq119.pdf Accessed December 23,2018.

35. Taylor EN, Stampfer MJ, Curhan GC. Dietary factors and the risk of incident kidney stones inmen: new insight safter 14 years of follow-up. J Am Soc Nephrol 2004;15(12):3225-32.

36. Hirvonen T, Pietinen P, Virtanen M, Albanes D, Virtamo J. Nutrient intake and use of beverages and the risk of kidney stones among male smokers. Am J Epidemiol 1999;150(2):187-94.

37. Pak CYC, Peterson R, Poindexter JR. Adequacy of a singlestone risk analysis in the medical evaluation of urolithiasis. J Urol 2001;165(2):378-81.

38. Sorensen MD, Hsi RS, Chi T, Shara N, Wactawski-Wende J, Kahn AJ, et al. Dietary intake of fiber, fruit, and vegetables decrease the risk of incident kidneystones in women: a Women's Health Initiative (WHI) report. J Urol 2014;192(6):1694-99.

39. Milicevic S, Bijelic R, Krivokuca V, Bojic M, PopovicPejicic S, Bojanic N. Correlation of the body mass index and calcium nephrolithiasis in adult population. Med Art 2013;67(6):423-7.

40. Fredric LC. The pathogenesis and treatment of kidney stones. NEJM 1992;327(16):1141-52. 